\title{
Cysteine-179 of IKB kinase $\beta$ plays a critical role in enzyme activation by promoting phosphorylation of activation loop serines
}

\author{
Mi-Sun Byun, Jin Choi and \\ Dae-Myung Jue ${ }^{1}$ \\ Department of Biochemistry, College of Medicine \\ The Catholic University of Korea \\ Seoul 137-701, Korea \\ ${ }^{1}$ Corresponding author: Tel, 82-2-590-1177; \\ Fax, 82-2-596-4435; E-mail, dmjue@catholic.ac.kr
}

\section{Accepted 20 September 2006}

Abbreviations: $15 \mathrm{dPGJ}_{2}$, 15-deoxy- $\triangle^{12-14}-\mathrm{PGJ}$; GST, glutathione S-transferase; HA, hemagglutinin; IKK, IKB kinase; MAPKKK, mitogen-activated protein kinase kinase kinase; MEKK, MAPK/ extracellular signal-regulated kinase kinase; NIK, NF-KB-inducing kinase

\begin{abstract}
IKB kinase $\beta$ (IKK $\beta$ ) subunit of IKK complex is essential for the activation of NF- $\mathrm{KB}$ in response to various proinflammatory signals. Cys-179 in the activation loop of IKK $\beta$ is known to be the target site for IKK inhibitors such as cyclopentenone prostaglandins, arsenite, and antirheumatic gold com pounds. Here we show that a mutant IKK $\beta$ in which Cys-179 is substituted with alanine had decreased activity when it was expressed in HEK-293 cells, and TNF stimulation did not restore the activity. Phos phorylation of activation loop serines (Ser-177 and Ser-181) which is required for IKK $\beta$ activation was reduced in the IKK $\beta$ (C179A) mutant. The activity of IKK $\beta$ (C179A) was partially recovered when its phosphorylation was enforced by coexpression with mitogen-activated protein kinase kinase kinases (MAPKKK) such as NF-kB inducing kinase (NIK) and MAPK/extracellular signal-regulated kinase kinase kinase 1(MEKK1) or when the serine residues were replaced with phospho-mimetic glutamate. The IKK $\beta$ (C179A) mutant was normal in dimer formation, while its activity abnormally responded to the change in the concentration of substrate ATP in reaction mixture. Our results suggest that Cys-179 of IKK $\beta$ plays a critical role in enzyme activation by promoting phosphorylation of activation-loop serines and
\end{abstract}

interaction with ATP.

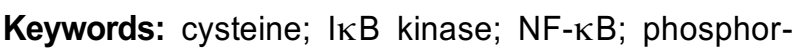
ylation; protein serine-threonine kinases

\section{Introduction}

Nuclear factor- $\mathrm{KB}(\mathrm{NF}-\mathrm{KB})$ is a transcription factor that regulates expression of a wide range of cellular and viral genes that play pivotal roles in immune and inflammatory responses (Barnes and Karin, 1997). In unstimulated cells, NF-KB is associated with inhibitory $1 \kappa B$ proteins that inhibit nuclear localization and DNA binding of NF- $\mathrm{KB}$. In response to stimuli including TNF, IL-1, LPS, or viruses, the IKBs are phosphorylated and subsequently degraded, releasing NF- $\mathrm{kB}$ to bind DNA and induce expression of specific target genes.

Phosphorylation of $I K B$ is one of the primary points of regulation in NF- $\mathrm{KB}$ activation pathway, and occurs by IKB kinase (IKK). IKK is present as a complex of $700 \mathrm{kDa}$ composed of two catalytic subunits, IKK $\alpha$ (or IKK1) and IKK $\beta$ (IKK2), and a regulatory subunit, IKK $\gamma / \mathrm{NEMO} / \mathrm{KKKAP} 1$ (May and Ghosh, 1998; Karin, 1999; Zandi and Karin, 1999). IKK $\alpha$ and IKK $\beta$ are Ser/Thr kinases of similar structure that can form homodimers and heterodimers. Studies with animals deficient in each IKK subunit revealed that IKK $\beta$ is essential for the activation of IKK in response to TNF and other proinflammatory stimuli, whereas IKK $\alpha$ plays roles during embryonic development of the skin and skeletal system (Karin, 1999; Zandi and Karin, 1999). Activation of the IKK complex involves the phosphorylation of specific serine residues (Ser-176/180 of IKK $\alpha$ and Ser-177/181 of IKK $\beta$ ) located in the "activation loop" within the kinase domains of IKK $\alpha$ and IKK $\beta$, and conversion of activation loop serines of IKK $\beta$ to alanine prevented IKK activation by TNF and IL-1 (May and Ghosh, 1998; Karin, 1999; Zandi and Karin, 1999). Certain mitogenactivated protein kinase kinase kinases (MAPKKK) including NF-KB-inducing kinase (NIK) and MAPK/ extracellular signal-regulated kinase kinase kinase 1 (MEKK1), MEKK2, MEKK3, were shown to induce phosphorylation and activation of IKK in cultured cells (Karin and Ben-Neriah, 2000). Another possible mechanism for IKK activation is through the activity 
of IKK itself. IKK $\alpha$ and IKK $\beta$ prepared by overexpression in mammalian cells and insect cells were fully active and phosphorylated at the activation loop (Zandi et al., 1997; 1998), and enforced dimerization of IKK $\alpha$ and IKK $\beta$ induced autophosphorylation of activation loop serines and enzyme activation (Inohara et al., 2000; Poyet et al., 2000; Tang et al., 2003). In this induced-proximity model proximity of IKK subunits induced by homotypic interaction or oligomerization of upstream signaling molecules followed by binding of IKK subunits to these molecules results in transautophosphorylation between IKK subunits and enzyme activation in the absence of help from other kinases.

Our previous study showed that thiol-reactive metal compounds such as gold, zinc, and copper inhibit NF-KB activation by blocking IKK in LPSstimulated macrophages (Jeon et al., 2000). Other thiol-reactive agents such as cyclopentenone PGs $\left[P \mathrm{PA}_{1}\right.$ and 15-deoxy- $\left.\triangle^{12-14}-\mathrm{PGJ}_{2}\left(15 \mathrm{dPGJ}_{2}\right)\right]$ (Rossi et al., 2000; Straus et al., 2000), arsenite anion $\left(\mathrm{AsO}_{3}{ }^{3-}\right)$ (Kapahi et al., 2000), parthenolide (Kwok et al., 2001), and epoxyquinone A (Liang et al., 2006) were also shown to inhibit NF-KB and IKK activation in cells stimulated with TNF, IL-1, and phorbol esters. It was reported that exposure of cells to oxidants such as hydrogen peroxide $\left(\mathrm{H}_{2} \mathrm{O}_{2}\right)$ and diamide suppressed TNF-induced NF- $\mathrm{KB}$ and IKK activation (Korn et al., 2001; Byun et al., 2002). These results suggest that a cysteine sulfhydryl group, which is easily modified by thiol-reactive or oxidizing agents, is critically involved in IKK activation or regulation of IKK activity. Cys-179 in the activation loop of IKK $\beta$ has been implicated as a target residue for these thiol-modifying agents and an IKK $\beta$ (C179A) mutant in which Cys-179 is replaced with alanine was resistant to inhibitory effect of $15 \mathrm{dPGJ}_{2}$, arsenite, parthenolide, and gold compounds (Kapahi et al., 2000; Rossi et al., 2000; Kwok et al., 2001; Jeon et al., 2003).

Here we examined the role of Cys-179 in regulation of IKK $\beta$ activity. We observed that IKK $\beta$ (C179A) mutant expressed in HEK-293 cells had reduced enzyme activity and its serine residues in the activation loop remained unphosphorylated. Partial recovery of IKK $\beta$ (C179A) activity was observed when these serines were enforced to be phosphorylated by coexpression with MAPKKKs or substituted with glutamate residues, indicating that IKK $\beta$ Cys-179 is involved both in phosphorylation of activation loop serines and in catalytic process.

\section{Materials and Methods}

\section{Materials}

Antibodies to FLAG and hemagglutinin (HA) tag were obtained from Stratagene (La Jolla, CA) and Santa Cruz Biotechnology (Santa Cruz, CA), respectively. Recombinant glutathione S-transferase (GST)I $\mathrm{B} \alpha$ containing $\mathrm{N}$-terminal 54 residues of $I \kappa B \alpha$ and recombinant human TNF were prepared by expression in Escherichia coli as described previously (Jeon et al., 2000). Expression vectors for FLAG-tagged IKK $\beta$ and IKK $\beta$ (S177/181E) were kindly provided by Dr. F. Mercurio (Signal Pharmaceuticals, San Diego, CA). Substitution of Cys-179 with alanine was carried out by site-directed mutagenesis as described previously (Jeon et al., 2003). The cDNA for wild type IKK $\beta$ was subcloned into Notl site of pcDNA 4T-2 which contains amino-terminal HA sequences. NIK and MEKK1 expression constructs were gifts from Dr. J.-H. Kim (Korea University, Seoul, Korea). The luciferase reporter plasmid lgkB-Luc was provided by Dr. T.-H. Lee (Yonsei University, Seoul, Korea).

\section{Cell culture, IKK assay and reporter assay}

HEK-293 and HeLa cells were obtained from the American Type Culture Collection (Manassa, VA), and maintained in DMEM supplemented with $10 \%$ heat-inactivated FBS, and antibiotics. Cells were transfected with expression vectors for IKK $\beta$ and their mutants using Fugene 6 (Roche Molecular Biochemicals, Mannheim, Germany) and incubated for $48 \mathrm{~h}$. Preparation of cytoplasmic extracts and immunoprecipitation were performed as described (Byun et al., 2002). Kinase activity was measured in reaction mixtures containing $10 \mu \mathrm{M}$ ATP, $\left[\gamma^{32}{ }^{32} \mathrm{P}\right] \mathrm{ATP}(2-5 \mu \mathrm{Ci})$ and GST-IKB $\alpha(1 \mu \mathrm{g})$ (Jeon et al., 2000). Reaction products were analyzed by SDS-PAGE on a $12.5 \%$ gel and electrophoretically transferred to nitrocellulose membrane. Phosphorylated GST-IKB $\alpha$ was visualized by autoradiography and quantitated in a phosphor image analyzer (Fujifilm, Tokyo, Japan). Proteins in the cell extracts were analyzed by immunoblotting using ECL system (Amersham Biosciences, Buckinghamshire, U.K.) (Byun et al., 2002). NF-KB reporter gene assay was performed in HeLa cells as described previously (Byun et al., 2002).

\section{Metabolic radiolabeling}

After transfection of expression plasmids for IKK $\beta$ and other proteins, HEK-293 cells were incubated for $24 \mathrm{~h}$ and labeled for $5 \mathrm{~h}$ with ${ }^{32} \mathrm{P}$ ]orthophosphate $(100 \mu \mathrm{Ci} / \mathrm{ml})$ in phosphate-free DMEM (Gibco BRL). The labeled cells were washed with an ice-cold PBS. Cytoplasmic extracts were prepared and IKK $\beta$ was immunoprecipitated using anti-FLAG antibody. Phosphoproteins were fractionated by SDS-PAGE, transferred to nitrocellulose membranes and visualized by autoradiography. 


\section{Coimmunoprecipitaion assay}

HEK-293 cells transfected with FLAG- or HA-IKK $\beta$ expression vectors were lysed and immunoprecipitated with anti-FLAG antibody as described previously (Byun et al., 2002). The immunocomplexes were washed three times with lysis buffer and once with PBS. Samples were separated by SDS-PAGE, and analyzed by immunoblotting with anti-HA or anti-FLAG antibodies.

\section{Results}

\section{Substitution of Cys-179 with alanine renders IKK $\beta$ inactive}

Cys- 179 of IKK $\beta$ is critically positioned within the activation loop, suggesting that this residue is required for enzyme activation or involved in regulation of enzyme activity. To test the role of this cysteine residue, we expressed wild type IKK $\beta$ or mutant enzymes, in which Cys-179 of IKK $\beta$ were replaced with alanine in HEK-293 cells. We then isolated the wild type and mutant enzymes by immunoprecipitation and measured their kinase activity in vitro (Figure 1A). Whereas wild type IKK $\beta$ was active, IKK $\beta$ (C179A) mutant showed reduced activity (Figure 1A). Stimulation of cells with TNF did not further increase the activity of wild type enzyme nor restored the activity of C179A mutant. We then determined whether the decreased activity of IKK $\beta$ (C179A) mutant observed in vitro reflect their NF-KB-inducing capabilities by measuring expression of NF-KB reporter gene in HeLa cells (Figure 1B). Expression of NF-KB reporter gene was greatly increased in cells transfected with wild type $\operatorname{IKK} \beta$, whereas it was significantly reduced in cells transfected with C179A mutant compared with wild type enzyme.

\section{Cys-179 is required for phosphorylation of activation loop serine residues}

IKK $\beta$ is activated by phosphorylation of Ser-177 and Ser-181 in its activation loop, and this was shown to be an essential step in the NF- $\kappa$ B activation (Mercurio et al., 1997; Delhase et al., 1999). Since Cys-179 is located in the activation loop between Ser-177 and Ser-181, we investigated whether the reduced activity of IKK $\beta$ (C179A) was caused by inhibition of Ser$177 / 181$ phosphorylation. Phosphorylation of activation loop serines was measured by metabolic labeling of HEK-293 cells with $\left[{ }^{32} \mathrm{P}\right]$ orthophosphate after the cells were transfected with wild type or mutant IKK $\beta$. As shown in Figure $1 \mathrm{~A}$, overexpression of wild type IKK $\beta$ lead to formation of active enzyme and autophosphorylation. In contrast, both enzyme activity and phosphorylation were reduced in IKK $\beta$ (C179A)
A

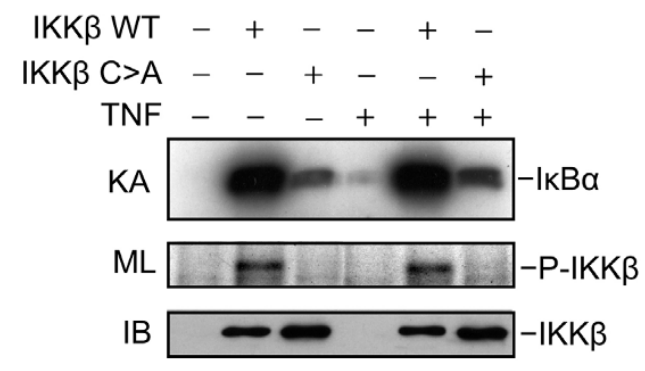

B

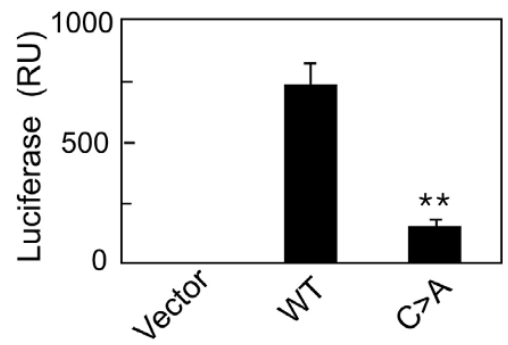

Figure 1. Substitution of Cys-179 with alanine reduces activity and phosphorylation of IKK $\beta$. (A) HEK-293 cells $\left(0.5 \times 10^{5}\right)$ were transiently transfected with expression vectors $(200 \mathrm{ng})$ for wild type $\operatorname{IKK} \beta(\mathrm{WT}), \operatorname{IKK} \beta(\mathrm{C} 179 \mathrm{~A})(\mathrm{C}>\mathrm{A})$ or with the same amount of empty vector (pFLAG-CMV). After $48 \mathrm{~h}$, a group of cells were treated with TNF $(20 \mathrm{ng} / \mathrm{ml})$ for $5 \mathrm{~min}$, the cells were lysed and kinase assay (KA) was performed with immune complex obtained from cell lysate $(20$ $\mu \mathrm{g}$ protein) (top). Another group of cells were metabolically radiolabeled (ML) with $\left.{ }^{32} \mathrm{P}\right]$ orthophosphate for $5 \mathrm{~h}$ before harvest. Cell extract (30 $\mu \mathrm{g}$ protein) was subjected to immunoprecipitation with anti-FLAG antibody, and the resultant immune complex was analyzed by SDS-PAGE and autoradiography (middle). The expression level of IKK $\beta$ was measured by immunoblotting (IB) with anti-FLAG antibody (bottom). (B) The same constructs were transiently transfected into HeLa cells together with expression vectors for NF- $\mathrm{\kappa B}$ reporter plasmid IgKB-Luc, and $\beta$-actin promoter-driven $\beta$-galactosidase expression plasmid. After $24 \mathrm{~h}$, whole cell extract was prepared and luciferase activity was determined using an assay kit (Promega, Madison, WI) and a luminometer. The data were normalized to the activity of cotransfected $\beta$-galactosidase expression vector. The results are presented as mean $\pm \mathrm{SD}(n=5)$ and the statistical significance was determined by Student's $t$-test. ${ }^{* *} P<0.01$ vs. wild type IKK $\beta$. The data represent three experiments.

mutant expressed in a similar level to wild type IKK $\beta$. Stimulation of cells with TNF did not induce further increase of phosphorylation of wild type IKK $\beta$ or IKK $\beta$ (C179A) mutant. Much of the autophosphorylation observed in wild type IKK $\beta$ was shown to occur at Ser-177/181, because phosphorylation was significantly decreased in IKK $\beta$ (S177E/S181E) mutant in which Ser-177 and Ser-181 were substituted with glutamate residues (Figure 2A).

To clarify whether the reduced activity of IKK $\beta$ $(C 179 A)$ is the cause or the result of its reduced phosphorylation at activation loop serines, we trans- 
A
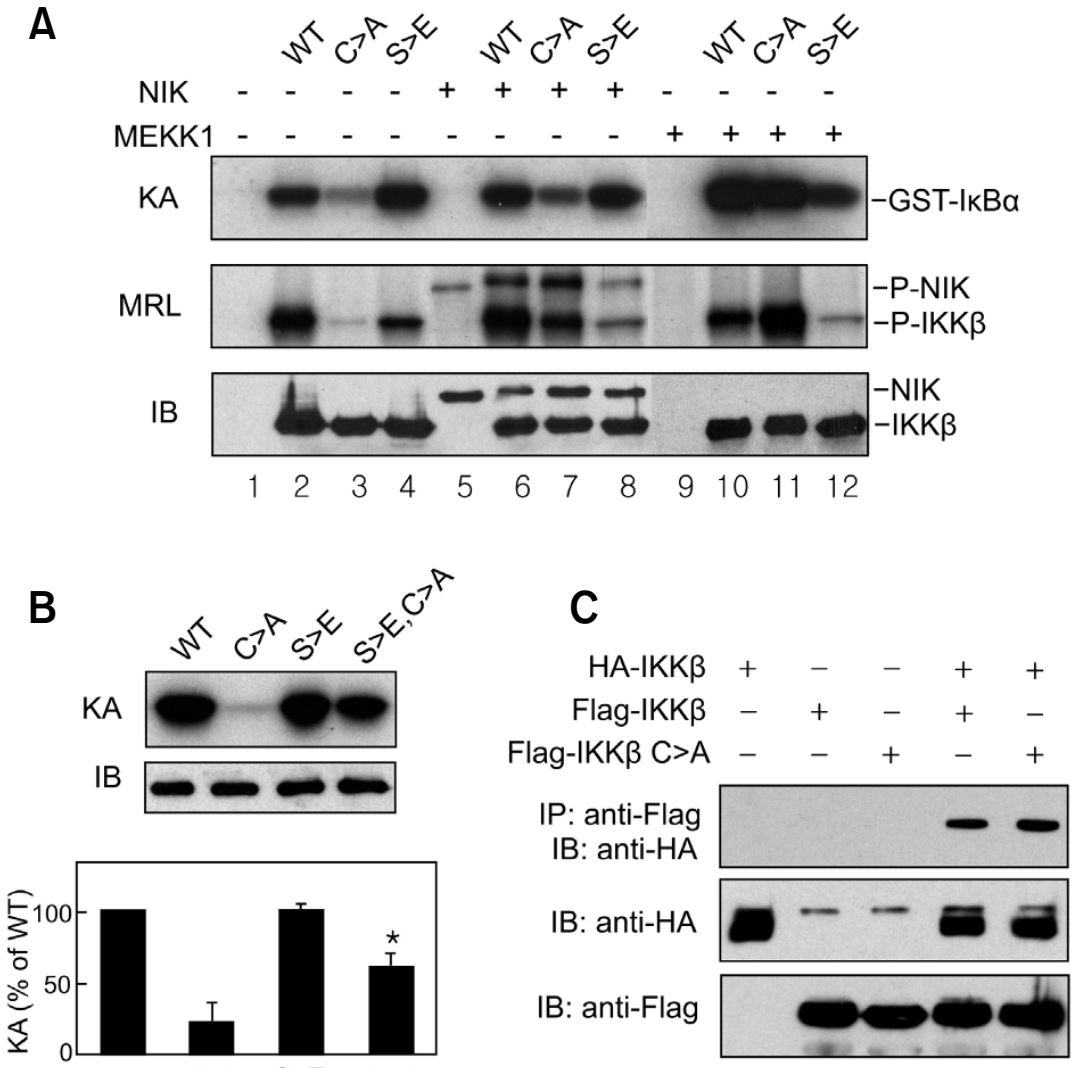

Figure 2. Phosphorylation of activation loop serines is inhibited by mutation of Cys-179. (A) HEK-293 cells $\left(1 \times 10^{5}\right)$ were transiently transfected with expression vectors for wild type IKK $\beta$

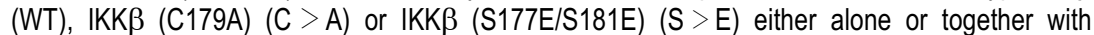
pFlagCMV2-NIK (30 ng) or pEECMV-MEKK1 (100 ng). Kinase activity and phosphorylation of expressed IKK $\beta$ and expression level were determined as described in Figure 1A. (B) HEK-293 cells were transfected with expression vectors for wild type IKK $\beta$ (WT), IKK $\beta(C 179 A)(C>A)$, IKK $\beta$ (S177E/S181E) (S >E), and IKK $\beta$ (S177E/ S181E/C179A) (S > E, C >A). IKK activity of expressed enzyme and expression level were determined as described in (A) (upper panel). IKK activity was determined by measuring the radioactivity of GST-IKB $\alpha$ by phosphor image analysis and calculated as a percent of control (lower histogram). The results are presented as mean \pm SD $(n=3)$ and the statistical significance was determined by Student's $t$-test. ${ }^{*} P<0.05$ vs. $\mathrm{S}>\mathrm{E}$. (C) HEK-293 cells were transiently transfected with indicated expression plasmids and lysed after $48 \mathrm{~h}$. Immunoprecipitates were prepared with anti-FLAG antibody, separated by SDS-PAGE, and probed using anti-HA antibody to detect coimmunoprecipitated protein (top). The cell lysate was also probed with anti-HA and anti-FLAG antibodies to measure the expression levels (middle and bottom). The data represent two independent experiments.

fected HEK-293 cells with expression vectors for NIK and MEKK1 along with IKK $\beta$ (C179A) expression vector. We used NIK and MEKK1 because they were shown to be able to directly activate and phosphorylate IKK $\beta$ (Lee et al., 1998; Nakano et al., 1998; Nemoto et al., 1998). Coexpression of NIK and MEKK1 with wild type IKK $\beta$ induced modest increase of IKK $\beta$ activity and phosphorylation (Figure $2 A)$. The effect of NIK and MEKK1 was more remarkable when they were expressed with IKK $\beta$ (C179A), and significant recovery of enzyme activity and phosphorylation was observed. However, the enzyme activity of IKK $\beta$ (C179A) expressed with NIK or MEKK1 was still lower than that of wild type IKK $\beta$ expressed with NIK or MEKK1. To further analyze the effect of Ser-177/181 phosphorylation on the activity of IKK $\beta$ (C179A), we prepared IKK $\beta$ (S177E/S181E/ C179A) mutant, in which Ser-177 and Ser-181 were substituted with phospho-mimetic glutamates and Cys-179 with alanine, and its kinase activity was measured (Figure 2B). As observed in cotransfection experiments, substitution of Ser-177/181 with 
A

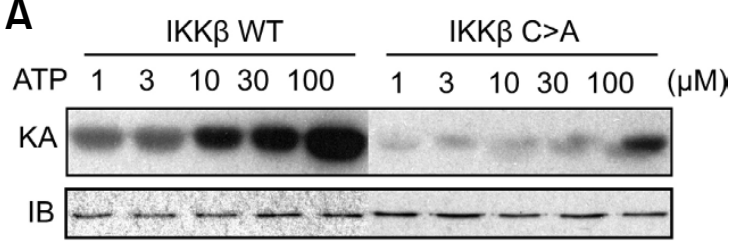

B

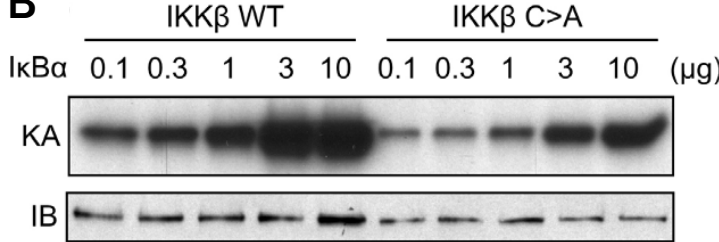

Figure 3. IKK $\beta(C 179 \mathrm{~A})$ mutant is insensitive to ATP concentration. HEK-293 cells $\left(0.5 \times 10^{5}\right)$ were transfected with expression vectors for wild type (WT) IKK $\beta$ and IKK $\beta(C 179 A)(C>A)$. The cell were lysed and IKK $\beta$ in the cell lysate was immunoprecipitated with anti-FLAG antibody. In vitro kinase assay (KA) was performed with the immunoprecipitate in the presence of various concentrations of $\left[\gamma^{32}\right.$ P]ATP and GST-IKB $\alpha$. The amounts of enzyme in the reaction mixture was determined by immunoblotting (IB) using anti-FLAG antibody. The data represent three independent experiments.

glutamate in $\operatorname{IKK} \beta(\mathrm{C} 179 \mathrm{~A})$ induced remarkable recovery of IKK $\beta$ (C179A) activity, although the recovery was not complete and the activity was $61 \%$ of wild type IKK $\beta$ or IKK $\beta$ (S177E/S181E) mutant.

Our result indicates that phosphorylation of activation loop serines was inhibited by C179A mutation in IKK $\beta$. Previous studies showed that activation loop serines of IKK $\beta$ is autophosphoryled when the enzyme is induced to form dimers by overexpression. To test whether $\mathrm{C} 179 \mathrm{~A}$ mutation inhibits IKK $\beta$ autophosphorylation by blocking dimerization of IKK $\beta$, HEK-293 cells were cotransfected with Flag- and $\mathrm{HA}$-tagged IKK $\beta$ and the binding of IKK $\beta$ monomers were determined by immunoprecipitation with antiFLAG antibody and immunoblotting with anti-HA antibody. Our result shown in Figure $2 \mathrm{C}$ revealed that binding of IKK $\beta(\mathrm{C} 179 \mathrm{~A})$ to other IKK $\beta$ subunit was not different from that of wild type IKK $\beta$.

\section{Cys-179 is involved in ATP binding or processing}

To study the cause of reduced activity of IKK $\beta$ (C179A), we tested the effect of various concentrations of substrates, ATP and $I \kappa B \alpha$, on its kinase activity. Our result showed that variation of ATP concentration in the reaction mixture did not induce considerable change in IKK $\beta(C 179 A)$ activity which was observed with the wild type enzyme (Figure $3 A$ ). In contrast, variation of $I \kappa B \alpha$ concentration caused concomitant change in the enzyme activity of both wild type IKK $\beta$ and IKK $\beta$ (C179A).

\section{Discussion}

In this study, we investigated the role of Cys-179 of IKKB in regulation of enzyme activity by using a mutant enzyme in which Cys-179 was replaced with alanine. Our results showed that IKK $\beta$ (C179A) mutant expressed in HEK-293 cells had lower activity than wild type enzyme, and was defective in inducing NF-KB reporter gene in transfected cells. Because Cys-179 is located in the activation loop of IKK $\beta$ between Ser-177 and Ser-181 whose phosphorylation is critical for enzyme activation (May and Ghosh, 1998; Karin, 1999; Zandi and Karin, 1999), we determined phosphorylation status of these serines in IKK $\beta$ (C179A). Our result showed that autophosphorylation that occurred in wild type IKK $\beta$ overexpressed in HEK-293 cells was greatly reduced by mutation of Cys-179. The decreased activity and phosphorylation of IKK $\beta$ (C179A) was not recovered by stimulation of cells with TNF, indicating Cys-179 is also required for signal-induced phosphorylation and activation of IKK $\beta$ in addition to dimerization-induced autophosphorylation and activation.

The concomitant decrease of enzyme activity and phosphorylation of activation loop serines suggested two possible modes for the effect of C179A mutation of IKK $\beta$ : (1) the loss of enzyme activity caused reduced phosphorylation, or (2) reduced phosphorylation caused the loss of enzyme activity. To determine which mode underlies the inhibitory effect of C179A mutation, we employed two methods, i.e. enforced phosphorylation of activation loop serines and substitution of these serines with glutamate residues. When the phosphorylation was enforced by coexpression of MAPKKKs (NIK and MEKK1), the activity of IKK $\beta$ (C179A) recovered significantly, although it was still lower than the activity of wild type enzyme. In experiments with IKK $\beta$ (S177E/S181E/C179A) mutant, substitution of Ser-177 and Ser-181 with phospho-mimetic glutamates also induced significant recovery of $\operatorname{IKK} \beta(\mathrm{C} 179 \mathrm{~A})$, but it was $61 \%$ of the activity of wild type IKK $\beta$ or IKK $\beta$ (S177E/S181E). Our results clearly indicated that, although the reduced phosphorylation caused the loss of enzyme activity in $\operatorname{IKK} \beta$ (C179A), the activity of phosphorylated IKK $\beta$ (C179A) was still lower than that of phosphorylated wild type IKK $\beta$. Thus it seems plausible that Cys-179 of IKK $\beta$ plays a dual role in regulation of enzyme activity in part by promoting phosphorylation of activation loop serines, and in part by other unknown mechanism in the phosphorylated enzyme.

Previous studies showed that overexpression of IKK $\beta$ induces dimerization and autophosphorylation between associated IKK $\beta$ subunits, and suggested that this proximity model of IKK activation is a 
mechanism for NF-кB activation induced by TNF and other ligands (Inohara et al., 2000; Poyet et al., 2000; Tang et al., 2003). To determine whether the decreased phosphorylation of IKK $\beta$ (C179A) was due to inhibition of dimerization, we measured dimerization between IKK $\beta$ and IKK $\beta$ (C179A) by coexpression experiment. Our result showed no change in the ability of dimerization in IKK $\beta$ (C179A) compared with wild type IKK $\beta$, suggesting that inhibition of phosphorylation itself, rather than inhibition of dimerization, is responsible for the decreased autophosphorylation of IKK $\beta$ (C179A).

In our kinase assay, the activity of $\operatorname{IKK} \beta$ (C179A) responded differently to the change in the concentrations of two substrates of IKK, ATP and $1 \kappa B \alpha$. Whereas the activity of $\operatorname{IKK} \beta$ (C179A) changed according to the concentration of $1 \kappa B \alpha$ in the reaction mixture, its response was largely muted to the change of ATP concentration. These results suggested that $\operatorname{IKK} \beta(\mathrm{C} 179 \mathrm{~A})$ is defective in binding or processing of ATP, and Cys-179 of IKK $\beta$ is involved in this catalytic process. In most protein kinases, the activation loop is located apart from the $\mathrm{N}$-terminal ATP-binding domain and is not directly involved in ATP binding (Johnson et al., 1996). It thus seems plausible that the role of Cys-179 is to promote phosphorylation-induced conformational shift in $\operatorname{IKK} \beta$, which is required for the formation of binding cleft for ATP. In this regard, our results also suggested that the binding site for $I K B \alpha$ in IKK $\beta$ is formed even in the absence of the activation loop phosphorylation.

Cys-179 of IKK $\beta$ has been implicated as an important target site for various anti-inflammatory thiolmodifying agents, including cyclopentenone prostaglandins (Rossi et al., 2000), arsenite (Kapahi et al., 2000), parthenolide (Kwok et al., 2001), gold compounds (Jeon et al., 2003), nitric oxide (Reynaert et al., 2004) and epoxyquinone A monomer (Liang et al., 2006). In these studies the effects of drugs were tested with IKK $\beta$ isolated from IKK $\beta$-overexpressing cells or cells stimulated with TNF and LPS, and the enzymes should be in fully activated (phosphorylated) form. It is not clear whether the inhibitory effect of these drugs appears through a mechanism similar to that of $\mathrm{C} 179 \mathrm{~A}$ mutation of IKK $\beta$. However, the results of these studies support our finding that Cys-179 of IKK $\beta$ participates in regulation of activated (phosphorylated) enzyme as well as phosphorylation of activation loop serines. It would be interesting to determine whether the agents binding Cys-179 of IKK $\beta$ inhibit phosphorylation of serines in the IKK $\beta$ activation loop in unstimulated cells, and the result would provide additional mechanism for the inhibition of NF-KB activation by the thiol-modifying drugs.

In summary, our results showed that Cys -179 of IKK $\beta$ is required for phosphorylation of Ser-177 and
Ser-181 in the activation loop of IKK $\beta$ and mutation of Cys-179 inhibits enzyme activation. Considering the essential role of activation loop phosphorylation in regulation of IKK activity, our results demonstrated that Cys-179, located between Ser-177 and Ser-181, is critically involved in regulation of IKK activity and $N F-\kappa B$ activation. NF- $\kappa B$ controls expression of diverse mediators of inflammatory and immune response and has been implicated in numerous chronic inflammatory diseases, including rheumatoid arthritis, asthma, inflammatory bowel disease, and ulcerative colitis (Barnes and Karin, 1997). Understanding the mode of IKK activation will benefit development of novel strategies to treat these diseases.

\section{Acknowledgement}

This work was supported by the Rheumatism Research Center grant of Korean Science and Engineering Foundation (\#R11-2002-098-07001-0). We thank Drs. F. Mercurio, J.-H. Kim, and T.-H. Lee for expression plasmids.

\section{References}

Barnes PJ, Karin M. Nuclear factor- $\mathrm{\kappa B}$ : a pivotal transcription factor in chronic inflammatory diseases. N Engl J Med 1997; 336:1066-71

Byun MS, Jeon KI, Choi JW, Shim JY, Jue DM. Dual effect of oxidative stress on NF- $\mathrm{KB}$ activation in HeLa cells. Exp Mol Med 2002; 34:332-9

Delhase M, Hayakawa M, Chen Y, Karin M. Positive and negative regulation of IKB kinase activity through IKK $\beta$ subunit phosphorylation. Science 1999;284:309-13

Inohara N, Koseki T, Lin J, del Peso L, Lucas PC, Chen FF, Ogura Y, Nunez G. An induced proximity model for NF-KB activation in the Nod1/RICK and RIP signaling pathways. J Biol Chem 2000;275:27823-31

Jeon KI, Jeong JY, Jue DM. Thiol-reactive metal compounds

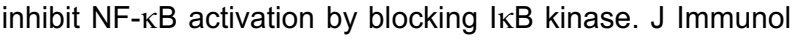
2000;164:5981-9

Jeon KI, Byun MS, Jue DM. Gold compound auranofin inhibits IKB kinase (IKK) by modifying Cys-179 of IKK $\beta$ subunit. Exp Mol Med 2003;35:61-6

Johnson LN, Noble ME, Owen DJ. Active and inactive protein kinases: structural basis for regulation. Cell 1996;85:149-58

Kapahi P, Takahashi T, Natoli G, Adams SR, Chen Y, Tsien RY, Karin M. Inhibition of NF-kB activation by arsenite through reaction with a critical cysteine in the activation loop of $1 \kappa B$ kinase. J Biol Chem 2000;275:36062-6

Karin M. The beginning of the end: I $\mathrm{KB}$ kinase (IKK) and NF- $\kappa B$ activation. J Biol Chem 1999;274:27339-42

Karin M, Ben-Neriah Y. Phosphorylation meets ubiquitination: the control of NF-KB activity. Annu Rev Immunol 2000;18: 
$621-63$

Korn SH, Wouters EF, Vos N, Janssen-Heininger YM. Cytokine- induced activation of nuclear factor- $\mathrm{KB}$ is inhibited by hydrogen peroxide through oxidative inactivation of $I \kappa B$ kinase. J Biol Chem 2001;276:35693-700

Kwok BH, Koh B, Ndubuisi MI, Elofsson M, Crews CM. The anti-inflammatory natural product parthenolide from the medicinal herb Feverfew directly binds to and inhibits IKB kinase. Chem Biol 2001;8:759-66

Lee FS, Peters RT, Dang LC, Maniatis T. MEKK1 activates both

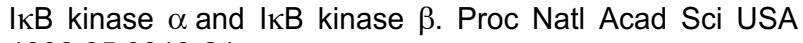
1998;95:9319-24

Liang MC, Bardhan S, Pace EA, Rosman D, Beutler JA, Porco JA, Gilmore TD. Inhibition of transcription factor NF- $\kappa B$ signaling proteins IKK $\beta$ and $p 65$ through specific cysteine residues by epoxyquinone A monomer: correlation with its anti-cancer cell growth activity. Biochem Pharmacol 2006:71:634-45

May MJ, Ghosh S. Signal transduction through NF-кB. Immunol Today 1998;19:1980-8

Mercurio F, Zhu H, Murray BW, Shevchenko A, Bennett BL, Li J, Young DB, Barbosa M, Mann M, Manning A, Rao A. IKK-1 and IKK-2: cytokine-activated IKB kinases essential for NF-kB activation. Science 1997;278:860-6

Nakano H, Shindo M, Sakon S, Nishinaka S, Mihara M, Yagita $\mathrm{H}$, Okumura K. Differential regulation of IKB kinase alpha and beta by two upstream kinases, NF- $\mathrm{kB}$-inducing kinase and mitogen-activated protein kinase/ERK kinase kinase-1. Proc Natl Acad Sci USA 1998;95:3537-42

Nemoto S, DiDonato JA, Lin A. Coordinate regulation of IKB kinases by mitogen-activated protein kinase kinase kinase
1 and NF-kB-inducing kinase. Mol Cell Biol 1998;18:7336-43

Poyet JL, Srinivasula SM, Lin JH, Fernandes-Alnemri T, Yamaoka S, Tsichlis PN, Alnemri ES. Activation of IкB kinases by RIP via IKK $\gamma /$ NEMO-mediated oligomerization. J Biol Chem 2000;275:37966-77

Reynaert NL, Ckless K, Korn SH, Vos N, Guala AS, Wouters $E F$, van der Vliet A, Janssen-Heininger YM. Nitric oxide represses inhibitory $\kappa B$ kinase through S-nitrosylation. Proc Natl Acad Sci USA 2004;101:8945-50

Rossi A, Kapahi P, Natoli G, Takahashi T, Chen Y, Karin M, Santoro MG. Anti-inflammatory cyclopentenone prostaglandins are direct inhibitors of IKB kinase. Nature 2000; 403:103-8

Straus DS, Pascual G, Li M, Welch JS, Ricote M, Hsiang CH, Sengchanthalangsy LL, Ghosh G, Glass CK. 15-Deoxy$\triangle^{12,14}$-prostagrandin $\mathrm{J}_{2}$ inhibits multiple steps in the NF-KB signaling pathway. Proc Natl Acad Sci USA 2000;97:4844-9

Tang ED, Inohara N, Wang CY, Nunez G, Guan KL. Roles for homotypic interactions and transautophosphorylation in IKB kinase $\beta$ (IKK $\beta$ ) activation. J Biol Chem 2003;278:38566-70

Zandi E, Rothwarf DM, Delhase M, Hayakawa M, Karin M . The IKB kinase complex (IKK) contains two kinase subunits, IKK $\alpha$ and IKK $\beta$, necessary for IKB phosphorylation and NF-KB activation. Cell 1997;91:243-52

Zandi $E$, Chen $Y$, Karin M. Direct phosphorylation of $\mathrm{I} K B$ by IKK $\alpha$ and IKK $\beta$ : discrimination between free and NF-KBbound substrate. Science 1998;281:1360-3

Zandi E, Karin M. Bridging the gap: composition, regulation, and physiological function of the I $\mathrm{kB}$ kinase complex. Mol Cell Biol 1999;19:4547-51 